\title{
REVIEW
}

\section{THE ANDREE DIARIES}

The finding of the bodies of Andrée and his two companions on White Island last summer, by its dramatic and tragic nature, has alrendy in many details been widely reported and published in the popular pross. The recently published Andrée Diaries provides the first fully connceted account. Apart from this, the book forms a basis for reconsidering Andrée's work and properly appreciating an adventure which at the time was very widely discussed and almost always adversely criticized. It many now be said that such views on Andrée are no longer possible, except froin those who are also prepared to comment adversely on Nansen's voyage in the Fram. Buth voyages consist of a drift, the one by air, the other locked in pack ice, into the centre of the unknown Arctic basin: followed in each case by a sledge journey over pack-ice towards land, and the necessity of wintering till travel was once more possible.

Andrée's balloon voyage lasted three days. At the very start (July 11, 1897) the guide ropes, on which the height at which it was hoped to drift depended, were broken off. The bylloon immediately rose to an cxcessive height, and very much more gas was lust than had been planned. Quite apart from reaching the Pole and travelling beyond, the balloon was unable to travel more than a comparatively short distance; loss of gas and unexpected fog brought her down in $82^{\circ} 56^{\prime} \mathrm{N}$., $29^{\circ} 56^{\prime}$ F. after a rigzang course of nearly 500 miles, and a distance made good of 288 miles northcast of the starting point.

The sledge journey started a week later, on July 21, with l'ranz Joset Land as the objective; this had to be given up, and the party then tried to reach northern Spitsbergen; finally wind and current made it necessary to land on White Island. 'The journey of over two months on the pack-ice is a splendid record of endurance and courage. The rate of travel, thongh seldom as high as three miles a day, must be considered cxceptionally good; the mileage was generally much less, and contrary winds and currents might easily have broken Andrée's spirit and resolve. This journey compares with De Long's after the loss of the Jeannette and with Nansen's in the later stages when near the ice edge and with water leads continually forming; the comparison is much in Andrée's fuvour.

The party drifted under the lee of White Island on September 18. They decided not to land, but to remuin on the ice, even though winter 
had practically set in. A snow and ice hut about $12 \mathrm{ft}$. by $6 \mathrm{ft}$. was built on a selected Hoe, and took ten days to make. Four days later the floe broke under the hut; the break was the result no doubt of a swell, showing that open water was very near. The party saw their labours at hut building lost and had no other obvious course but to land on White Island; this appears to have taken place successfully on October 5.

After this date the records become scanty. Andrée, who had made only intermittent diary entries since September 23, a period during which work on the ice hut kept them very busy, appears to have made a long entry again on October 5 and 6 after the landing. Unfortunately this part of his diary is only partly legible, but the portions which can be read, taken together with the long account of the journey on the packice, point to the party having landed in good spirits and physically sound; there had been plenty of food, and even a certain amount of leisure. At this period, Strindberg, probably also through lack of time, only made very brief entries in his almanac:

Oct.

5 Tu. Moved to land.

$6 \mathrm{~W}$ : Suowstorm. Reconnoitring.

7 Th. Moving.

17 S. Home 7.5 cl. a.m.

It seems fair to conclude that during the ten days between October 7 and October 17 every effort was being inade to construct a second winter hut, this time on land. Strindberg's last entry is a perfectly natural one, and suggests a bear hunt, and inability to return immediately owing to darkness or, if on the pack-ice, owing to adverse wind and tide.

When the bodies were found, those of Andrée and Fraenkel were lying in the position of death in a marked-off area about $13 \mathrm{ft}$. by $6 \mathrm{ft}$. In the official account this area is described as a tent, but its great size, Andrée's apparent intentions as shown in his log, and Strindberg's previous success on the pack-ice make it almost certain that, in addition to a tent lining, a hut of snow and ice must have stood here.

The ultimate cause of death is ascribed to cold and insufficient clothing. This conclusion is not altogether borne out by published evidence. Andrée had previous experience in wintering in Spitsbergen, bundles of unused clothing were found in the camp, and there was no lack of balloon silk which must have been nearly windproof. Apart from these facts, the absence of diary entries (it is not made clear whether further entries were made and are now obliterated) after records written as occasion offered 
and in good spirit, would suggest some other explanation, and that death when it came was sudden. This does not seem the place to discuss all the possibilities, but it seems not impossible that a re-examination may show that Andrée lost his life, not through lack of foresight in choosing his clothing, but by some chance and unexpected misfortune, when shelter and food were assured, and there was every appearance of safety and security.

J. M. W. 